\title{
BENEFITS FROM TREE SPECIES' DIVERSIFICATION IN COCOA AGROFORESTS IN THE CENTRE REGION OF CAMEROON
}

\author{
Achille Jean Jaza Folefack $^{1 \star}$, Lea Yvonne Eboutou ${ }^{2}$, Ann Degrande $^{2}$, \\ Thérèse Fouda Moulende ${ }^{1}$, François Kamajou ${ }^{1}$, Siegfried Bauer ${ }^{3}$ \\ ${ }^{1}$ Department of Agricultural Economics, University of Dschang, Cameroon \\ ${ }^{2}$ World Agroforestry Centre, West and Central Africa-Humid Tropics, Cameroon \\ ${ }^{3}$ Institute for Project and Regional Planning, University of Giessen, Germany
}

*E-mail: ajazafol@yahoo.fr

\begin{abstract}
This paper analyses the profitability of cocoa farmers in the Centre region of Cameroon who wish to diversify their activity by associating inside their orchards several species of domestic fruit trees. Hence, by using linear programming and financial appraisal tools, eight agroforest systems are compared in order to deduct the most beneficial one. The results show that, priority should be given to the most enriched agroforest (Cocoa+Safout+Mango+Ndjansang) which is the most beneficial/productive one for resources use. It provides the highest Net Present Value (19,398 Euros/ha), Internal Rate of Return (52.7\%) and Benefit Cost Ratio (8.20) as well as the shortest Pay Back Period (4 years), confirming that it is the most beneficial combination. Hence, to earn higher income, farmers should adopt the most diversified agroforest and the government should encourage trees' regeneration and cocoa farm extension.
\end{abstract}

\section{KEY WORDS}

Agroforest, Cocoa, Gross Margin, Linear Programming, Shadow Price,Trees' Species.

Before the 1990s economic crisis in Cameroon, the income of rural farmers reached the highest level with cocoa sales representing an important part of their revenues. The cocoa production was highly subsidized at that time by the State because its sales constituted the main source of foreign currency gains and provided significant revenues to farmers. Cocoa and coffee altogether contributed to about $28 \%$ of non-petroleum export products and $40 \%$ of exports of primary sector. The cocoa sector alone represented about $2 \%$ of the country's GDP, $6 \%$ of agricultural GDP and $30 \%$ of sub-sectoral GDP of agricultural products devoted to exports and processing. It provided a yearly revenue ranging between 132,969 to 248,663 FCFA/ha (about 203 to 379 Euros/ha), which was sufficient at that period for producers to sustain their livelihoods. In 1985 for instance, the cocoa production contributed to $50-75 \%$ of the budget of $90 \%$ of households in the Centre region of the country (Ministry of Agriculture, 2014).

However with the economic crisis of the early 1990s, the State was obliged to disengage from all sectors and take particular measures for cocoa producers (removal of subsidy for credit, fertilizers, pesticides, seeds, etc) in order to restrict the public expenditures and boost the country's economy. In this respect, the liberalization of the marketing of cocoa and coffee products was the major measure adopted under the structural adjustment program of International Monetary Fund (IMF) and World Bank.

But, the accompanying measures to liberalization were so weak that, instead of bringing the envisaged solutions, they rather plunged the cocoa producers into total poverty. These producers faced a lack of appropriate pests' treatment of orchards and the difficulty of commercialization due to the dissolution of the former National Product Marketing Board (NPMB) in charge of price stabilization of cocoa and coffee. During the same period, the decline of prices of cocoa in the world market also worsened the farmer livelihoods. As a consequence, all cocoa producers recorded a sudden drop of their incomes without any guarantee of reversing the situation (Varlet, 1991). The major consequence was an impoverishment of farmers (hunger, health and education problems), globally perceived in the traditional cocoa producing zones (Jagoret et al., 2006; Degrande et al., 2007). 
In response to this situation, cocoa producers adopted a different behavior for producing at low cost in a liberalized context materialized by a limited access to credit and inputs (VARLET, 1991). The most important measure of farmers' adaptation was the diversification of their cocoa farms and namely, the integration of fruit trees inside their cocoa orchards. This consisted of preserving fruit trees' species such as safout (Dacryodes edulis), ndjansang (Ricinodendron heudelotii), and bush mango (Irvingia spp.) which grow spontaneously in the cocoa plantation or are planted by the farmer. According to Jagoret et al. (2006) and Degrande et al. (2007), preserving these domestic fruit trees could protect cocoa from sunshine because the cocoa trees grown in direct sunlight without the protection of shade can suffer from heat stress. The high temperature and the intense sun can thereby affect the health of the plant and ultimately decrease yields and the quality of the harvest. Implementing agroforestry methods, where such taller growing native trees provide shade and decrease the temperature on the farm, is important to help farmers adapt their cocoa trees to climate change (Jagoret et al., 2006; Degrande et al., 2007). Such agroforestry methods would be of great utility in the Centre region, where the old age of cocoa orchards (above 20 years of age) and farmers (above 50 years of age) and mainly the lack of maintenance and inadequate shading provided to cocoa plants is the main cause of the low cocoa yield (less than $300 \mathrm{~kg} / \mathrm{ha}$ as compared to an expected yield of $1000 \mathrm{~kg} / \mathrm{ha}$ in modern exploitations) recorded in this locality since the liberalization of the early 1990s (Jagoret et al., 2006; Degrande et al., 2007; Ministry of Agriculture, 2014).

Thus, combining/associating these domestic fruit trees inside the cocoa orchards is necessary for providing optimum shade to cocoa and sustaining maximum crop yield so as to overcome major difficulties faced by farmers in this region. In this respect, some innovative strategies were developed to improve the cocoa farming system, while protecting the environment and improving the livelihoods of the rural producers/farmers. Among these strategies, is the program of domestication of local fruit trees and medicinal species launched in 1996 in Cameroon by ICRAF/WAC ${ }^{1}$. This program sensitizes rural farmers to acquire tree domestication skills and also to diversify their cocoa plantations with local fruit trees such as safout, ndjansang, bush mango, etc. However, the profitability of cocoa agroforests enriched with domestic fruit trees has not yet been evaluated, which may limit their adoption by the farmers who are the main beneficiaries. Hence, the objective of the study is to evaluate the profitability and resources' productivity in enriched agroforest systems (cocoa associated with domestic trees' species) as compared to the traditional cocoa system (cocoa alone).

\section{MATERIALS AND METHODS}

Study Area and Data Collection. This study was carried out by using the available ICRAF database collected from April to August 2008 from a sample of 1428 farmers producing cocoa and associated trees' species in the production basin of the Centre region of Cameroon (Jagoret et al., 2008). This area was selected because cocoa (Theobroma cacao Linn.) is the main cash crop occupying $90 \%$ of farmers in the region and it is a zone where cocoa yields are declining (because of the old age of cocoa orchards and farmers), thus needing new strategies to increase productivity.

In this area, farmers (averaging 50 years of age) are in most cases the owners of cocoa orchards which are very old (above 20 years of age) and lack maintenance so that the cocoa yield is always very low (less than $300 \mathrm{~kg} / \mathrm{ha}$ as compared to an expected yield of $1000 \mathrm{~kg} / \mathrm{ha}$ in modern exploitations) (Ministry of Agriculture, 2014). Because of these reasons, ICRAF/WAC chose the region for implementing its program of domesticated trees' species incorporated within the cocoa plantations (launched in this area since 1996). Hence, in order to benefit from the available facilities and database of that program, the same region was preferred and chosen for this study.

The trees' species were chosen according to their presence in the area, market potential and farmers' preference. On this basis, species such as safout (Dacryodes edulis),

${ }^{1}$ ICRAF=International Centre for Research in Agroforestry; WAC=World Agroforestry Centre. 
ndjansang (Ricinodendron heudelotii) and bush mango (Irvingia gabonensis) were chosen as trees to be associated with cocoa (Theobroma cacao Linn.).

From the available ICRAF database and more precisely from the survey by Jagoret et al. (2008), we were interested in this paper to use mainly the data such as the: yield, market price and forecasted gross margin of cocoa and fruit species (safout, ndjansang, bush mango), prices and intensities of application of inputs (mineral fertilizer, animal manure, labour, capital, irrigation, seeds, pesticides, insecticides, herbicides, etc) used to cultivate the trees' species, cultivated land area, level and interest rate of credit use, density of plantation of trees' species, price of agricultural tools, etc.

Data Codification and Processing. All the possible associations/combinations of cocoa with safout, ndjansang and bush mango were considered. Hence, the traditional cocoa system was compared with the enriched agroforest systems by considering the following eight combinations: Cocoa alone [C], Cocoa plus Safout $[\mathrm{C}+\mathrm{S}]$, Cocoa plus Mango [C+M], Cocoa plus Ndjansang [C+N], Cocoa plus Safout plus Mango [C+S+M], Cocoa plus Safout plus Ndjansang $[\mathrm{C}+\mathrm{S}+\mathrm{N}]$, Cocoa plus Mango plus Ndjansang $[\mathrm{C}+\mathrm{M}+\mathrm{N}]$, Cocoa plus Safout plus Mango plus Ndjansang [C+S+M+N].

\section{ANALYTICAL TECHNIQUES}

In order to achieve the study objective, mainly the financial appraisal (FA) and linear programming (LP) techniques are used in this paper. The mathematical expressions of the FA tools used in the analysis are indicated in Appendix 1. This section focuses on the mathematical expressions of the farmer's gross margin and resources availabilities considered in the LP model.

By definition, the gross margin is the enterprise's contribution toward fixed costs and profit after the variable costs have been paid. Hence, the farmer's gross margin (GM) from trees' species cultivated in the enriched agroforests is derived by subtracting the total variable costs (TVC) [i.e. costs for purchasing inputs] from the total revenue (TR) [i.e. gains from the sales of fruits harvested in the farm]. It is mathematically expressed as:

\section{GM=TR-TVC}

For a given farm situation, the linear programming model requires a specification of the farm activities, resources constraints of the farm and the forecast gross margin of farm activities (Hazell and Norton, 1986). In this paper, we need to know the trees' species combinations which maximize the farmer's gross margin, given the constraints of available resources of land, labour, capital, credit and trees' species. Hence, the activities which enter into the programming model are all cocoa-based combinations of trees' species made of $\mathrm{C}+\mathrm{S}+\mathrm{M}+\mathrm{N}, \mathrm{C}+\mathrm{S}+\mathrm{M}, \mathrm{C}+\mathrm{M}+\mathrm{N}, \mathrm{C}+\mathrm{S}+\mathrm{N}, \mathrm{C}+\mathrm{M}, \mathrm{C}+\mathrm{S}, \mathrm{C}+\mathrm{N}$, and $\mathrm{C}-$ only.

The gross margin (GM) of equation (1) implies that any rational farmer in the study area would wish to achieve the maximum of such a linear function while diversifying his cocoa-based activities. From the field reality, we assume that a farmer maximizes his total gross margin (GM) subject to the constraints he faces such as the availabilities of land, labour, capital, credit limit and trees' species. The problem is summarized in the linear programming tableau of Appendix 2.

In Table $A_{2}$ (Appendix 2), the Right Hand Side (RHS) column includes data on the farmer's yearly resource availabilities according to Jagoret et al. (2008). These are 2.35 ha for land, 136 mandays for labour, 275 Euros for capital and 1525 plants of trees' species. Besides, the study considers that, the production of 1 hectare of the trees' species combination made of $\mathrm{C}+\mathrm{S}+\mathrm{M}+\mathrm{N}$ requires 225 mandays of labour, 351 Euros of capital and 1267 plants. The basic requirements for the production of 1 ha of other trees' species combinations made of $\mathrm{C}+\mathrm{S}+\mathrm{M}, \mathrm{C}+\mathrm{M}+\mathrm{N}, \mathrm{C}+\mathrm{S}+\mathrm{N}, \mathrm{C}+\mathrm{M}, \mathrm{C}+\mathrm{S}, \mathrm{C}+\mathrm{N}$, and $\mathrm{C}$-only are also shown in other columns of that tableau (Eboutou , 2010; Jagoret et al., 2008). The forecasted gross margins per ha of activities are: 4587, 4109, 3767, 3089, 2693, 2390, 2292, and 99 Euros for the $\mathrm{C}+\mathrm{S}+\mathrm{M}+\mathrm{N}, \mathrm{C}+\mathrm{S}+\mathrm{M}, \mathrm{C}+\mathrm{M}+\mathrm{N}, \mathrm{C}+\mathrm{S}+\mathrm{N}, \mathrm{C}+\mathrm{M}, \mathrm{C}+\mathrm{S}, \mathrm{C}+\mathrm{N}$, and $\mathrm{C}$-only 
combinations of trees' species, respectively. These are computed from secondary data taken from Eboutou (2010), Jagoret et al. (2008) and Todem (2005) by using equation (5) of the previous section. Additionally, every farmer sustains its activities by borrowing money from local banks at an annual interest rate of $18 \%$ and the maximum credit amount is generally limited to $30 \%$ of farmer's own funds/capital i.e. $0.30 \star 275=82.5$ Euros (Eboutou, 2010; Jagoret et al., 2008) (see Appendix 2, Table $A_{2}$ ).

From Table $A_{2}$ (Appendix 2), the detailed mathematical equations of the linear programming model for this study are:

$$
\text { Max GM=99X } X_{1}+2292 X_{2}+2390 X_{3}+2693 X_{4}+3089 X_{5}+3767 X_{6}+4109 X_{7}+4587 X_{8}-0.18 X_{9}
$$

Subject to constraints:

$$
\begin{gathered}
1 \mathrm{X}_{1}+1 \mathrm{X}_{2}+1 \mathrm{X}_{3}+1 \mathrm{X}_{4}+1 \mathrm{X}_{5}+1 \mathrm{X}_{6}+1 \mathrm{X}_{7}+1 \mathrm{X}_{8}+0 \mathrm{X}_{9} \leq 2.35 \text { [Land availability] } \\
95 \mathrm{X}_{1}+145 \mathrm{X}_{2}+125 \mathrm{X}_{3}+145 \mathrm{X}_{4}+175 \mathrm{X}_{5}+195 \mathrm{X}_{6}+175 \mathrm{X}_{7}+225 \mathrm{X}_{8}+0 \mathrm{X}_{9} \leq 136 \text { [Labour availability] } \\
229 \mathrm{X}_{1}+244 \mathrm{X}_{2}+305 \mathrm{X}_{3}+260 \mathrm{X}_{4}+320 \mathrm{X}_{5}+275 \mathrm{X}_{6}+336 \mathrm{X}_{7}+351 \mathrm{X}_{8}-1 \mathrm{X}_{9} \leq 275 \text { [Capital availability] } \\
0 \mathrm{X}_{1}+0 \mathrm{X}_{2}+0 \mathrm{X}_{3}+0 \mathrm{X}_{4}+0 \mathrm{X}_{5}+0 \mathrm{X}_{6}+0 \mathrm{X}_{7}+0 \mathrm{X}_{8}+1 \mathrm{X}_{9} \leq 82.5 \text { [Credit limit] } \\
1111 \mathrm{X}_{1}+1127 \mathrm{X}_{2}+1181 \mathrm{X}_{3}+1181 \mathrm{X}_{4}+1197 \mathrm{X}_{5}+1197 \mathrm{X}_{6}+1251 \mathrm{X}_{7}+1267 \mathrm{X}_{8}+0 \mathrm{X}_{9} \leq 1525 \text { [Trees availability] }
\end{gathered}
$$

For the computations of various mathematical formulas and equations, FA was done by using EXCEL for Windows whereas LP was carried out with the GAMS ${ }^{2}$ software program.

\section{RESULTS AND DISCUSSIONS}

Results and Discussions from the Appraisal of Cocoa Agroforests with Net Present Value, Internal Rate of Return, Pay Back Period and Benefit Cost Ratio:

Net Present Value (NPV). By using a discount rate of $18 \%$ (which was the credit interest rate of money borrowed from Cameroonian banks at the moment of data collection in 2008), the Net Present Value (NPV) for each agroforest system is computed and presented in Table 1. The results indicate that, the traditional system made of "cocoa-only (C)" shows a negative NPV whereas the rest of the seven other enriched agroforest systems display positive NPV. This testifies that, all the enriched agroforests are profitable whereas the traditional "cocoa-only (C)" system is not gainful.

With a NPV of 19,398 Euros/ha, the quadruple species combination $[\mathrm{C}+\mathrm{S}+\mathrm{M}+\mathrm{N}]$, known as the most diversified agroforest, is also the most beneficial system. It is followed by agroforests combining three species $(\mathrm{C}+\mathrm{S}+\mathrm{M}, \mathrm{C}+\mathrm{M}+\mathrm{N}, \mathrm{C}+\mathrm{S}+\mathrm{N})$ which show NPV of 18,303 Euros/ha; 11,675 Euros/ha; 10,435 Euros/ha, respectively. The enriched agroforests containing two species $(\mathrm{C}+\mathrm{M}, \mathrm{C}+\mathrm{S}, \mathrm{C}+\mathrm{N})$ appear afterwards with NPV of 8,659 Euros/ha; 7,136 Euros/ha; and 1,336 Euros/ha, respectively. Lastly, the traditional "cocoa-only" (C) system displays a negative NPV suggesting that, it is not beneficial; thus should not be a good option to the farmers (see Table 1).

More explicitly, the negative NPV obtained by growing "cocoa alone" implies that, it would not be profitable if this tree is not planted in combination with other fruits' species. Hence, creating a cocoa farm in mono-crop would be a loss of time and energy because such investment would not add supplementary revenues to farmers.

In the field, the negative NPV of the "cocoa-only (C)" system could be explained by the low cocoa yield currently observed in the Centre region (less than $300 \mathrm{~kg} / \mathrm{ha}$ as compared to the expected $1000 \mathrm{~kg} / \mathrm{ha}$ in modern exploitations) and to the fact that, our computations take into account all the elements of costs (such as the costs of family labour, animal manure, irrigation's water, etc) which are often neglected by farmers because they take these inputs "free of charge" from their own farms without considering their monetary value.

Nevertheless, although the cocoa-only $(\mathrm{C})$ is the least profitable system, this species should not be totally eliminated from the farming system even if the sole goal is to maximize

\footnotetext{
${ }^{2}$ GAMS=General Algebraic Modeling System
} 
the income. This is because, it cultivation maximizes the decision-makers' objectives in reason of the important the role of this cash crop as devise gains and for satisfying various household needs in the country for the past decades. For this purpose, a sensitivity analysis was undertaken for this crop and its results reveal that, the "cocoa-only (C)" system becomes profitable when the discount rate is dropped to $13.5 \%$. In the Cameroonian context, this could never be achieved because that interest rate is below the current annual rate of $18 \%$ applied by most banking institutions in the country. Economically explained, a farmer who invests his money by growing "cocoa alone" would never gain any profit to sustain his livelihood or family unless the commercial banks drop their interest rate to $13.5 \%$ (which is almost impossible because of the $4-5 \%$ inflation rate in vigor in Cameroon) or if the government subsidizes (for instance by the difference of $18-13.5=4.5 \%$ ) the production of this crop as in the previous decades in the country. However, in the absence of any government subsidy, farmers should be advised to invest funds borrowed at an $18 \%$ banks' interest rate into the most diversified agroforest systems. By doing so, the NPV would change from negative to positive and higher value thanks to the trees' species associated to cocoa which would contribute to the increase of the economic value of cocoa.

The comparison of computed NPV from different systems testifies that, the association with the mango species gives more value to agroforests (see Table 1). This might be because the mango fruit has a higher commercial value per kilogram of product as compared to the other agroforest species (Eboutou, 2010). On average, mango fruit is sold at 3.81 Euros $/ \mathrm{kg}$ whereas cocoa, safout and ndjansang fruits are sold at respectively 1.52 Euros $/ \mathrm{kg}$, 0.91 Euros $/ \mathrm{kg}$ and 1.22 Euros $/ \mathrm{kg}$. Hence, it would be more profitable to advertise the marketing or multiplication of mango seedlings so as to encourage farmers to associate that fruit tree in the diversification of their agroforests.

Internal Rate of Return (IRR). Computed figures of Internal Rate of Return (IRR) confirm the same tendency already shown from NPV results. In Table 1, apart from the "cocoa-only (C)" system, all the seven other enriched agroforests have IRR greater than $41 \%$, so are profitable because these values stand above the $18 \%$ interest rate of funds borrowed in Cameroonian banking institutions.

The quadruple species' agroforest $(\mathrm{C}+\mathrm{S}+\mathrm{M}+\mathrm{N})$ is the most beneficial system because of its highest IRR (around 52.7\%). It is immediately followed by the triple species' agroforests $(\mathrm{C}+\mathrm{S}+\mathrm{M}, \mathrm{C}+\mathrm{M}+\mathrm{N}, \mathrm{C}+\mathrm{S}+\mathrm{N})$, all of them with IRR ranging between 47.4-49.3\%. The double species' agroforests $(\mathrm{C}+\mathrm{N}, \mathrm{C}+\mathrm{S}, \mathrm{C}+\mathrm{M})$ appear at next positions with IRR ranging within the interval $41.3-43.9 \%$. The "cocoa-only (C)" system ranks in the last position with an IRR of $13.4 \%$ (see Table 1 ).

In short, the more an agroforest system is diverse, the higher is its IRR (see Table 1). Hence, if we have to advise the farmers, we should recommend them to adopt the most diversified agroforest $[\mathrm{C}+\mathrm{S}+\mathrm{M}+\mathrm{N}]$. It is also remarked that all combinations with the mango species should be encouraged since they always appear at the first or second position within their group. We already mentioned the high commercial value of mango to explain this fact. This observation is important for farmers to decide on the more productive/beneficial types of tree species to associate together if they want to diversify their agroforests. Most farmers being illiterate in the study area, they need advices from government authorities/technicians for choosing the most suitable combination to adopt in the field. The classification of agroforests by their respective IRR (Table 1) could enable government, NGOs, banks, etc to decide on the systems where money should firstly be invested in order to improve the livelihoods of farmers in this locality.

Pay Back Period (PBP). The Pay Back Period (PBP) computed for all agroforest systems indicated the same tendency already explained with NPV and IRR. In general, the PBP figures in Table 1 indicate that, the more an agroforest system is enriched, the earlier we could recover the initial capital which was invested in it. The four species agroforest $(\mathrm{C}+\mathrm{S}+\mathrm{M}+\mathrm{N})$ records the lowest PBP (ranking thereby at the first position) since the capital invested in it was recovered after only 4 years. It is followed by the agroforests containing three species which are recovered after 5-6 years $(\mathrm{C}+\mathrm{S}+\mathrm{M}, \mathrm{C}+\mathrm{M}+\mathrm{N}, \mathrm{C}+\mathrm{S}+\mathrm{N})$. The money invested in the agroforests made of two species $(\mathrm{C}+\mathrm{M}, \mathrm{C}+\mathrm{S}, \mathrm{C}+\mathrm{N})$ is recovered after 7-8 
years, placing this sub-group at the third position. Lastly, the results show that, we should not hurry up to recover money invested by growing "cocoa alone" because such investment is recovered later after 17 years (see Table 1).

The PBP is usually used in financial appraisal to select between several speculations with nearly similar IRR. In such a case, the best agroforest which would attract the investors is the one with the smallest PBP (Siebert, 2008; Turner et al., 1993). From the IRR results (Table 1), seven systems (apart from the "cocoa-only [C]" system) recorded acceptable IRR $>41 \%$ (higher than the $18 \%$ bank's interest rate), thereby rendering difficult to select the best alternative based on that criteria. However, with the computations of PBP (Table 1), there is no doubt that the most diversified agroforest $[\mathrm{C}+\mathrm{S}+\mathrm{M}+\mathrm{N}]$ has the shortest PBP (4 years) and thus is the best one to be popularized to farmers of the Centre region.

The economic reason justifying these PBP results stand about the differences in initial investment and cumulated cash flow generated from each agroforest system. The more an agroforest system is enriched, the quicker its investment charges are compensated by cash flow from the sales of its fruits. Hence, banking institutions would not hesitate too much to award credit to farmers diversifying agroforests since they are almost sure that their money would be refunded in shorter period of time.

Benefit Cost Ratio (BCR). The computed Benefit Cost Ratio (BCR) of enriched agroforest systems are also indicated in Table 1 . The results show that, the agroforest combining four species $[\mathrm{C}+\mathrm{S}+\mathrm{M}+\mathrm{N}]$ is the most beneficial one since it records the highest BCR (8.20) ranking at the $1^{\text {st }}$ position. It is followed by the three species' agroforests occupying the $2^{\text {nd }}, 3^{\text {rd }}$ and $4^{\text {th }}$ positions $(\mathrm{C}+\mathrm{S}+\mathrm{M}, \mathrm{C}+\mathrm{M}+\mathrm{N}, \mathrm{C}+\mathrm{S}+\mathrm{N}$ with $\mathrm{BCR}$ of $7.58,7.10$, 6.00 , respectively). The agroforests containing two species rank from the $5^{\text {th }}$ to $7^{\text {th }}$ positions $(\mathrm{C}+\mathrm{M}, \mathrm{C}+\mathrm{S}, \mathrm{C}+\mathrm{N}$ with $\mathrm{BCR}$ of $5.48,5.05,5.00$, respectively). Lastly, with the smallest BCR (1.35), the "cocoa-only $(C)$ " system occupies the $8^{\text {th }}$ position (see Table 1 ). Hence, the more an agroforest is enriched with several trees' species, the higher is its BCR. This classification of agroforests based on BCR criteria gives the same ranking already obtained from the NPV, IRR and PBP approaches (see Table 1). Therefore, we would advise farmers to adopt the most diversified agroforest generating higher returns.

Results and Discussions for Assessing the Most Beneficial and Productive Agroforests from the Linear Programming Model:

Farmer's Gross Margin in Enriched Agroforests. Under the optimal conditions, the linear programming model displays a farmer's gross margin of 4,699 Euros/ha per year (see Table 2). This amount is very close to the profit currently earned by the "early adopters" of agroforest diversification in the field, thereby confirming the model validation. However, this farmer's gross margin could have been higher if most farmers were adapted to the modern cultivation techniques, which is unfortunately not the case at present. This might be due to the fact that farmers in this region are not yet familiar to cultivate new trees' species such as safout, ndjansang and bush mango. They still need time to be trained in order to learn the planting methods and management techniques for growing these new trees' species, and hence one needs to be patient for them to adopt the innovative strategies of tree domestication programme launched by ICRAFMAC.

Currently, most farmers of this region are only familiar with the cultivation of cocoa which was introduced in their locality as cash crop since several decades. The fact that the cocoa trees were introduced long time ago in this locality implies that, they have very old age nowadays and are not any more productive for farmers to earn high income by growing it in association with any local fruit species (safout, ndjansang, bush mango). Hence, another strategy for the government to improve the farmer's gross margin would be to regenerate cocoa trees in aged farms of the area or to replace all old cocoa trees by the youngest ones in such plantations. This cocoa regeneration project should be put at the agenda of the supervising institutes such as ICRAF/WAC who should also advertise the cocoa plantation while popularizing the local fruits' domestication programme. In short, the government action

\footnotetext{
"Early adopter" is a farmer who embraces new innovation or technology (such as agroforest diversification) before it becomes widely known or used by other people in the village.
} 
should not only be directed towards the popularization of the cocoa plantations; but it should also favour the implementation of the agroforest systems i.e. encourage the cultivation of cocoa plants in association with the domestic fruit species (mango, safout, ndjansang) so as to improve the income and living conditions of most farmers in this zone.

One of the advantages for farmers to adopt the ICRAF/WAC local fruit trees' domestication programme would be the numerous ecological gains from these trees such as the soil fertility improvement, ground protection from heating, conservation of biodiversity of several flora and fauna species, cocoa trees' protection against high storm, wind, and shade provision, etc. A previous study by Sonwa et al. (2000) already proves that, thanks to the detritus made of leaves and compost from agroforests' species, cocoa plants of the region could benefit from a free biomass supply reaching 304 tons/ha per year. Consequently, stimulating the habits of farmers in the Centre region for agroforestry practices would help to save money previously used to purchase mineral fertilizer while protecting the environment at the same time. In this view, the government should encourage farmers of this locality to achieve this challenge in future through the diversification of their agroforests.

Optimal Density and Productivity of Trees' Species in Enriched Agroforests. In Table 2, the linear programming model suggests that the trees' species should be planted at the optimal densities of $824,817,797,789,790,782,762$, and 755 plants/ha respectively for the $\mathrm{C}+\mathrm{S}+\mathrm{M}+\mathrm{N}, \mathrm{C}+\mathrm{S}+\mathrm{M}, \mathrm{C}+\mathrm{M}+\mathrm{N}, \mathrm{C}+\mathrm{S}+\mathrm{N}, \mathrm{C}+\mathrm{M}, \mathrm{C}+\mathrm{S}, \mathrm{C}+\mathrm{N}$, and $\mathrm{C}$ agroforest systems. These optimal densities are situated within the interval range of 700-2000 plants/ha previously observed by Jagoret et al. (2006), confirming the validity of model results which reflect the field reality. For each of the seven enriched agroforests, Table 2 shows the equality between the upper value and the optimal density of trees' species which testifies that, the domestic trees' species are scarce resources when they are combined in association with cocoa. However, for the cocoa-only $(\mathrm{C})$ system, there is still a rest of cocoa plants which remains unused ( 1111 minus $755=356$ plants/ha) probably because of the lack of domestic trees to be used in combination to the association.

Nevertheless, the productivity of the agroforest systems is increased when large numbers of domestic trees' species are grown in association to cocoa. In Table 2, we can see the different marginal productivities (shadow prices) of trees' species in various agroforests which testify this assertion. These shadow prices suggest that, an association of the $\mathrm{N}$ species to the existing $\mathrm{C}+\mathrm{S}+\mathrm{M}$ (so as to form the $\mathrm{C}+\mathrm{S}+\mathrm{M}+\mathrm{N}$ agroforest) would lead to an increase in farmer's gross margin by $191.310 \mathrm{Euros} / \mathrm{ha}$ (see Table 2). In the same view, the farmer's gross margin would be increased by 175.877, 110.782, 101.00 Euros/ha if we associate $M$ species to the existing $\mathrm{C}+\mathrm{S}$ combination (so as to form the $\mathrm{C}+\mathrm{S}+\mathrm{M}$ agroforest), $\mathrm{N}$ species to the existing $\mathrm{C}+\mathrm{M}$ combination (so as to form the $\mathrm{C}+\mathrm{M}+\mathrm{N}$ agroforest), $\mathrm{N}$ species to the existing $\mathrm{C}+\mathrm{S}$ combination (so as to form the $\mathrm{C}+\mathrm{S}+\mathrm{N}$ agroforest, respectively (see Table 2). Likewise, an association of either N, S, M species to the cocoa-only (C) system (so as to form the $\mathrm{C}+\mathrm{N}, \mathrm{C}+\mathrm{S}, \mathrm{C}+\mathrm{M}$ agroforests) would increase the farmer's gross margin by 814.28, 683.27, 89.37 Euros/ha, respectively. In short, the highest marginal productivity (shadow price) of trees' species is observed for the quadruple species combination $(\mathrm{C}+\mathrm{S}+\mathrm{M}+\mathrm{N})$, followed by the triple species combination (in the order by $\mathrm{C}+\mathrm{S}+\mathrm{M}, \mathrm{C}+\mathrm{M}+\mathrm{N}$, $\mathrm{C}+\mathrm{S}+\mathrm{N}$ ), then by the double species combination (in the order by $\mathrm{C}+\mathrm{M}, \mathrm{C}+\mathrm{S}, \mathrm{C}+\mathrm{N}$ ), and lastly by the cocoa-only $(\mathrm{C})$ system.

A previous study by Mbile et al. (2007) explains the importance of associating cocoa with taller trees such as ndjansang (with more than 20 meters height) and with trees of moderate height such as mango and safout (with height between 5 to 20 meters) in the cocoa protection for its growth and productivity. We already mentioned in the introduction that, cocoa trees grown in direct sunlight without the protection of shade can suffer from heat stress. The high temperature and the intense sun can thereby affect the health of the plant and ultimately decrease yields and the quality of the harvest. Hence, implementing agroforestry methods, where taller growing native trees provide shade and decrease the temperature on the farm, is important to help farmers adapt their cocoa trees to climate change (Jagoret et al., 2006; Degrande et al., 2007). 
Therefore, the highest marginal productivity of the most diversified agroforest $(\mathrm{C}+\mathrm{S}+\mathrm{M}+\mathrm{N})$ might be due to the fact that the system is constituted by a good combination made with a mixture of both the tallest and trees of medium height [the tallest tree (ndjansang) is grown in the highest stratum, mango and safout are grown in the medium stratum, cocoa is planted alone in the lowest stratum]. In the same view, Mbile et al. (2007) in a previous research in the Centre region of Cameroon demonstrates that, in order to obtain optimal productivity, we should not forget to combine domestic trees in association with cocoa by considering a maximum shading space of $68 \%, 24 \%$ and $8 \%$ for the trees' species of highest, medium and lowest strata, respectively. The most diversified agroforest $(\mathrm{C}+\mathrm{S}+\mathrm{M}+\mathrm{N})$ takes into account this shading spacing consideration and its highest marginal productivity could also be justified in light with this fact.

In Table 2, we already highlighted a zero marginal productivity for the cocoa-only (C) system which indicates that, this system is not in need of additional cocoa trees since there is still an excess or unused plants at the disposal of the farmers. Hence, an increase in the density of plantation of this species beyond the optimal level would have none impact on the farmer's gross margin (see Table 2). Doing that would be a waste of resource because cocoa tree is not a scarce resource under the existing farming conditions. This result is easily understood from the historical vocation of cocoa activities attributed to the farmers from the Centre region of Cameroon. We already mentioned the government support and the important role of cocoa activities in sustaining the livelihood of farmers of this region before the 1990s economic crisis in the country. So, the fact that cocoa was grown in mono-crop in the region for several decades explains the large availability of cocoa trees in the area. In the past, the government invested a lot of money to sustain the cocoa producers including the facilities to produce the cocoa seedlings and trees (e.g. subsidies for seedlings, free treatment of orchards, credit award at low interest rate, etc). But that is unfortunately not the case for other domestic trees' species such as mango, safout and ndjansang which did not benefit from a support policy from the government and which have just been recently popularized in the region thanks to the ICRAF/WAC program of trees' domestication.

\section{CONCLUSION AND RECOMMENDATIONS}

This study aims to estimate and compare the profitability of traditional cocoa system with enriched agroforests in the Centre region of Cameroon. Results from the financial appraisal indicate that, the most enriched agroforest $(\mathrm{C}+\mathrm{S}+\mathrm{M}+\mathrm{N})$ offers the highest Net Present Value (NPV=19,398 Euros/ha), Internal Rate of Return (IRR=52.7\%), Benefit Cost Ratio ( $B C R=8.20)$, and the shortest Pay Back Period ( $P B P=4$ years). The computed IRR and PBP are important indicators that money is more productive if it is invested in the most diversified agroforests in this locality. This is meaningful in a developing country's context like Cameroon where credit opportunity is rare, so that banking institutions would likely prefer to borrow their money to those farmers who would refund it more quickly and easily. Hence, the farmers adopting the most diversified agroforest systems could get higher chances for credit awards.

The study also computes the optimal level and productivity of resources' use in the enriched agroforests. According to the linear programming model results, farmers could earn a maximum gross margin of 4,699 Euros/ha per year under the optimal conditions of resources availabilities such as land, labour, capital, credit limit, and trees' species. From these results, the most interesting combination which allows an efficient use of farm resources is the quadruple species combination $(\mathrm{C}+\mathrm{S}+\mathrm{M}+\mathrm{N})$, followed by the triple species combination (in the order by $\mathrm{C}+\mathrm{S}+\mathrm{M}, \mathrm{C}+\mathrm{M}+\mathrm{N}, \mathrm{C}+\mathrm{S}+\mathrm{N}$ ), then by the double species combination (in the order by $\mathrm{C}+\mathrm{M}, \mathrm{C}+\mathrm{S}, \mathrm{C}+\mathrm{N}$ ), and lastly by the cocoa-only (C) system. Without surprise, the agroforest combinations that were better performing with financial appraisal tools appear at the same positions with the linear programming model.

As policy recommendations, the government action should not only be directed towards the popularization of the cocoa plantations; but it should also favour the implementation of the agroforest systems i.e. encourage the cultivation of cocoa plants in 
association with the domestic fruit species (mango, safout, ndjansang) so as to improve the income and living conditions of most farmers in this zone. Policies to extend the diversification to trees' species other than mango, safout and ndjansang should also be envisaged in the future.

\section{ACKNOWLEDGEMENTS}

The authors are grateful to the World Agroforestry Centre of Cameroon for its financial support for the data collection. Data analysis was undertaken through research fellowships from the Alexander von Humboldt Foundation $(\mathrm{AvH})$ in Germany which is also acknowledged.

\section{REFERENCES}

1. Degrande, A., H. Essomba, C.A. Bikoué Mekongo and A. Kamga. 2007. Domestication, Genre et Vulnérabilité. Participation des Femmes, des Jeunes, et des Catégories les plus Pauvres à la Domestication des Arbres Agroforestiers au Cameroun. Working Paper $\mathrm{N}^{\circ}$ 48. ICRAF/WAC, Yaoundé, Cameroon.

2. Eboutou, L.Y. 2010. Rentabilité Financière des Agroforêts à Base de Cacao Enrichies par des Arbres Domestiqués: Cas du Bassin de Production du Centre-Sud au Cameroun. Mémoire de Fin d'Etudes. Faculté d'Agronomie et des Sciences Agricoles, Université de Dschang, Cameroun.

3. Jagoret, P., N.H. Todem, E. Bouambi, J.L. Battini and S. Nyassé. 2006. Caractérisation des Systèmes de Cacaoculture du Centre-Cameroun. IRAD/CIRAD. Yaoundé, Cameroun.

4. Jagoret, P., N.H. Todem, E. Bouambi, J.L. Battini and S. Nyassé. 2008. Diversification des Exploitations Agricoles à Base de Cacaoyer au Centre-Cameroun: Mythe ou Réalité? Biotechnol. Agron. Soc. Environ., 13 (2) 2: 271-280.

5. Hazell, P.B. and R.D. Norton. 1986. Mathematical Programming for Economic Analysis in Agriculture. Macmillan Publishing Company, New York, USA.

6. Mbile, P., A. Tsobeng and A. Degrande. 2007. Intégration et Gestion des Arbres dans les Champs. Manuel d'Aide à la Décision. ICRAF, Yaoundé, Cameroun.

7. Ministry of Agriculture. 2014. Annuaire des Statistiques du Secteur Agricole, Campagne 2012/2013. Division des Etudes et Projets Agricoles, Cellule des Enquêtes et Statistiques, Yaoundé, Cameroun.

8. Siebert, H. 2008. Economics of the Environment, Seventh Edition. Springer Verlag, Berlin, Heidelberg, Germany.

9. Sonwa, D.J., S.F. Weise, M. Tchatat, A.B. Nkongmeneck, A. Adesina, O. Ndoye and J. Gockowski. 2000. Les Agroforêts Cacao: Espace Intégrant Développement de la Cacaoculture, Gestion et Conservation des Ressources Forestières au Sud-Cameroun. Paper Presented at the Second Pan African Symposium on the Sustainable Use of Natural Resources in Africa. Ouagadougou, Burkina Faso, 24-27 July 2000.

10. Todem, N.H. 2005. Bilan Financier des Systèmes de Cacaoculture du Centre-Cameroun. Mémoire de Fin d'Etudes. Faculté d'Agronomie et des Sciences Agricoles, Université de Dschang, Cameroun.

11. Turner, K., D. Pearce and I. Bateman. 1993. Environmental Economics: an Elementary Introduction. Johns Hopkins University Press, Baltimore, Maryland, Great Britain.

12. Varlet, F. 1991. Dynamique de Plantation et Stratégies des Planteurs dans les Zones Cacaoyères et Caféières de Makénéné et Ndikiniméki (Centre-Cameroun). Rapport de Stage Effectué à la SODECAO. Yaoundé, Cameroun. 


\section{APPENDIX 1: MATHEMATICAL FORMULAS FOR THE COMPUTATION OF THE NET PRESENT VALUE (NPV), INTERNAL RATE OF RETURN (IRR), PAY BACK PERIOD (PBP) AND BENEFIT COST RATIO (BCR) FOR ENRICHED AGROFOREST SYSTEMS}

Appendix 1.1: Net Present Value ${ }^{4}$ (NPV)

$$
N P V=\frac{\sum_{t=1}^{n}\left(B_{t}-C_{t}\right)}{(1+i)^{t}}
$$

Appendix 1.2: Internal Rate of Return ${ }^{5}$ (IRR)

$\mathrm{NPV}=0$ at IRR so that:

$$
\frac{\sum_{t=1}^{n}\left(B_{t}-C_{t}\right)}{(1+I R R)^{t}}=0
$$

Appendix 1.3: Pay Back Period ${ }^{6}(P B P)$

$\mathrm{C}_{0}=\Sigma \mathrm{B}_{\mathrm{t}}$ at PBP so that:

$$
P B P=\frac{C_{0}}{\sum B_{t}}
$$

Appendix 1.4: Benefit Cost Ratio $(B C R)$

$$
B C R=\frac{\sum_{t=1}^{n} B_{t}}{t} / \frac{\sum_{t=1}^{n} C_{t}}{t}
$$

Where:

NPV: Net Present Value (in Euros/ha); IRR: Internal Rate of Return (in \%); PBP: Pay Back Period (in years); BCR: Benefit Cost Ratio; $\mathbf{B}_{\mathbf{t}}$ : Gross Benefits (in Euros/ha); $\mathbf{C}_{0}$ : Initial Investment (in Euros/ha); $\mathbf{C}_{\mathbf{t}}$ : Total Costs (in Euros/ha); i: Discount (Interest) Rate in commercial banks, considered as $18 \%$ in this paper; $\mathbf{t}$ : Time Horizon with $t=1,2,3$,

25; $\mathbf{n}$ : Total Number of Years the agroforest system lasts (life span), which is considered as 25 in this paper.

\footnotetext{
${ }^{4} \mathrm{NPV}$ is the difference in monetary terms, between the discounted flow of benefits and the discounted flow of costs of the agroforest system over its life span.

${ }^{5}$ IRR is the discount rate which, when applied to the future streams of costs and benefits of any agroforest system, will produce a NPV of zero.

${ }^{6} \mathrm{PBP}$ is the period of time that it takes for the total (undiscounted) gross benefits of the agroforest system to compensate the (undiscounted) initial investment.

${ }^{7} \mathrm{BCR}$ is the ratio of undiscounted benefits by the undiscounted costs of any agroforest system during the entire lifespan of agroforest.
} 


\section{APPENDIX 2:}

Table $\mathrm{A}_{2}$ - Linear programming tableau of the problem

\begin{tabular}{|c|c|c|c|c|c|c|c|c|c|c|c|}
\hline \multicolumn{2}{|c|}{ Decision variables } & $\underset{0}{\stackrel{\sqrt[\pi]{c}}{E}}$ & 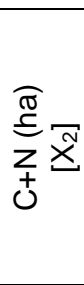 & 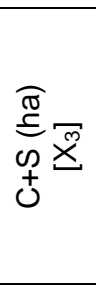 & 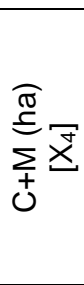 & 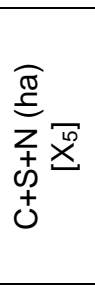 & 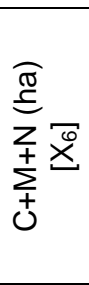 & $\begin{array}{l}\underset{\widetilde{\sigma}}{\Xi} \\
\sum_{+} \widetilde{\widetilde{x}} \\
0 \\
0 \\
0\end{array}$ & 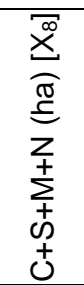 & 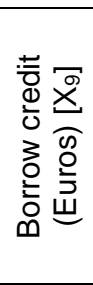 & $\begin{array}{l}\text { RHS } \\
\text { (Goal) }\end{array}$ \\
\hline \multicolumn{2}{|c|}{$\begin{array}{l}\text { Objective function } \\
\text { (GM in Euros/ha) }\end{array}$} & 99 & 2292 & 2390 & 2693 & 3089 & 3767 & 4109 & 4587 & -0.18 & Maximize \\
\hline \multirow{5}{*}{ 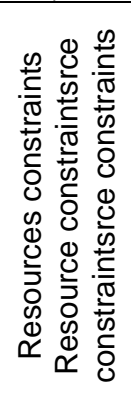 } & Land (ha) & 1 & 1 & 1 & 1 & 1 & 1 & 1 & 1 & 0 & $\leq 2.35$ \\
\hline & $\begin{array}{c}\text { Labour } \\
\text { (manday/h } \\
\text { a) }\end{array}$ & 95 & 145 & 125 & 145 & 175 & 195 & 175 & 225 & 0 & $\leq 136$ \\
\hline & $\begin{array}{c}\text { Capital } \\
\text { (Euros/ha) }\end{array}$ & 229 & 244 & 305 & 260 & 320 & 275 & 336 & 351 & -1 & $\leq 275$ \\
\hline & $\begin{array}{l}\text { Credit limit } \\
\text { (Euros/ha) }\end{array}$ & 0 & 0 & 0 & 0 & 0 & 0 & 0 & 0 & 1 & $\leq 82.5$ \\
\hline & $\begin{array}{c}\text { Trees' } \\
\text { species } \\
\text { (plants/ha) }\end{array}$ & 1111 & 1127 & 1181 & 1181 & 1197 & 1197 & 1251 & 1267 & 0 & $\leq 1525$ \\
\hline
\end{tabular}

Notes: $C=$ Cocoa; $S=S a f o u t ; M=M a n g o ; N=N d j a n s a n g ; G M=G r o s s$ Margin.

Source: Prepared according to Hazell and Norton (1986) with data from Eboutou (2010); Jagoret et al. (2008); Todem (2005)

Table 1 - Value and rank of Net Present Value (NPV), Internal Rate of Return (IRR), Pay Back Period (PBP) and Benefit Cost Ratio (BCR) for enriched agroforest systems

\begin{tabular}{|c|c|c|c|c|c|c|}
\hline \multirow{2}{*}{\multicolumn{2}{|c|}{ Agroforest systems }} & \multicolumn{4}{|c|}{ Financial appraisal tool } & \multirow{3}{*}{$\begin{array}{c}\text { Overall ranking (from } \\
\text { highest to lowest } \\
\text { performance) }\end{array}$} \\
\hline & & \multirow{2}{*}{$\begin{array}{c}\text { NPV (in } \\
\text { Euros/ha) } \\
-408\end{array}$} & \multirow{2}{*}{$\begin{array}{c}\begin{array}{c}\mathrm{IRR} \\
\text { (in \%) }\end{array} \\
13.4\end{array}$} & \multirow{2}{*}{$\begin{array}{c}\text { PBP (in } \\
\text { years) }\end{array}$} & \multirow{2}{*}{$\begin{array}{l}\text { BCR } \\
1.35\end{array}$} & \\
\hline $\begin{array}{l}\text { Single/None } \\
\text { combination }\end{array}$ & C & & & & & \\
\hline \multirow{3}{*}{ Double combination } & $\mathrm{C}+\mathrm{N}$ & $+1,336$ & 41.3 & 8 & 5.00 & $7^{\text {th }}$ \\
\hline & $\mathrm{C}+\mathrm{S}$ & $+7,136$ & 42.8 & 8 & 5.05 & $6^{\text {th }}$ \\
\hline & $\mathrm{C}+\mathrm{M}$ & $+8,659$ & 43.9 & 7 & 5.48 & $5^{\text {th }}$ \\
\hline \multirow{3}{*}{ Triple combination } & $\mathrm{C}+\mathrm{S}+\mathrm{N}$ & $+10,435$ & 47.4 & 6 & 6.00 & $4^{\ln }$ \\
\hline & $\mathrm{C}+\mathrm{M}+\mathrm{N}$ & $+11,675$ & 48.6 & 5 & 7.10 & $3^{\text {rd }}$ \\
\hline & $\mathrm{C}+\mathrm{S}+\mathrm{M}$ & $+18,303$ & 49.3 & 5 & 7.58 & $2^{\text {nd }}$ \\
\hline Quadruple combination & $\mathrm{C}+\mathrm{S}+\mathrm{M}+\mathrm{N}$ & $+19,398$ & 52.7 & 4 & 8.20 & $1^{\text {st }}$ \\
\hline
\end{tabular}

Notes: $C=$ Cocoa; $S=S a f o u t ; M=M a n g o ; ~ N=N d j a n s a n g$.

Source: Computed results from financial appraisal in EXCEL

Table 2 - Lower, level, upper and marginal productivity of trees' species and farmer's gross margin in enriched agroforests

\begin{tabular}{|c|c|c|c|c|c|}
\hline \multicolumn{2}{|c|}{$\mathrm{n} / \mathrm{n}$} & Lower & $\begin{array}{c}\text { Level } \\
\text { (optimal solution) }\end{array}$ & Upper & $\begin{array}{c}\text { Marginal productivity } \\
\text { (shadow price) }\end{array}$ \\
\hline \multicolumn{2}{|c|}{ Gross Margin (Euros/ha) } & -INF & 4699 & + INF & 0 \\
\hline \multirow{8}{*}{$\begin{array}{l}\text { Trees' species } \\
\text { (plants/ha) }\end{array}$} & $\mathrm{C}$ & 0 & 755 & 1111 & 0 \\
\hline & $\mathrm{C}+\mathrm{N}$ & 0 & 762 & 762 & 89.37 \\
\hline & $\mathrm{C}+\mathrm{S}$ & 0 & 782 & 782 & 683.27 \\
\hline & $\mathrm{C}+\mathrm{M}$ & 0 & 790 & 790 & 814.28 \\
\hline & $\mathrm{C}+\mathrm{S}+\mathrm{N}$ & 0 & 789 & 789 & 101.00 \\
\hline & $\mathrm{C}+\mathrm{M}+\mathrm{N}$ & 0 & 797 & 797 & 110.782 \\
\hline & $\mathrm{C}+\mathrm{S}+\mathrm{M}$ & 0 & 817 & 817 & 175.877 \\
\hline & $\mathrm{C}+\mathrm{S}+\mathrm{M}+\mathrm{N}$ & 0 & 824 & 824 & 191.310 \\
\hline
\end{tabular}

Notes: $C=$ Cocoa; $S=S a f o u t ; M=M a n g o ; N=$ Ndjansang; INF=Infinity.

Source: Base-run results from GAMS linear programming model 